\title{
Frequency of Various Risk Factors in HCV Positive Patients in Initial Diagnostic Phase
}

\author{
Anwar Ali Jamali ${ }^{*}$, Ghulam Mustafa Jamali ${ }^{1}$, Ameer Ali Jamali ${ }^{2}$, Bhojo Mal Tanwani ${ }^{3}$, \\ Niaz Hussain Jamali ${ }^{3}$, Arsalan Ahmer Rajput ${ }^{4}$, Moti Ram Bhatia ${ }^{5}$
}

\begin{abstract}
${ }^{1}$ Department of Medicine, Peoples University of Medical and Health Sciences, Nawabshah, Pakistan ${ }^{2}$ Department of Pediatrics, Peoples University of Medical and Health Sciences, Nawabshah, Pakistan ${ }^{3}$ Department of Physiology, Peoples University of Medical and Health Sciences, Nawabshah, Pakistan ${ }^{4}$ Department of Pharmacy, Peoples University of Medical and Health Sciences, Nawabshah, Pakistan ${ }^{5}$ Department of Psychiatry, Peoples University of Medical and Health Sciences, Nawabshah, Pakistan Email: ^jamalianwarali@gmail.com
\end{abstract}

How to cite this paper: Jamali, A.A., Jamali, G.M., Jamali, A.A., Tanwani, B.M., Jamali, N.H., Rajput, A.A. and Bhatia, M.R. (2018) Frequency of Various Risk Factors in HCV Positive Patients in Initial Diagnostic Phase. Occupational Diseases and Environmental Medicine, 6, 23-36.

https://doi.org/10.4236/odem.2018.62002

Received: February 8, 2018

Accepted: March 27, 2018

Published: March 30, 2018

Copyright $\odot 2018$ by authors and Scientific Research Publishing Inc. This work is licensed under the Creative Commons Attribution International License (CC BY 4.0).

http://creativecommons.org/licenses/by/4.0/

(c) (i) Open Access

\begin{abstract}
Viral hepatitis $\mathrm{C}$ is a type of illness, which is transmitted to patients by different methods in world. Here we will identify the different common risk factors for transmission of viral hepatitis $\mathrm{C}$ in our setup. Aim of study was to determine frequency of various risk factors in HCV positive patients. This study was cross sectional and conducted Department of Medicine PMC Hospital at Nawabshah. Duration of this study was one year from April 2016 to March 2017. After taking informed written consent, 243 diseased persons with positive anti Hepatitis $C$ Antibodies were incorporated in this research. Frequency of variables i.e. Hepatitis $\mathrm{C}$ virus risk factors and different other demographic results was collected on preformed proforma. In total of 243 subjects there were $165(67.9 \%)$ male and $78(32.1 \%)$ females respectively. Most of the subjects have more than one risk factor. 19 (7.8\%) had history of blood and blood products transfusion. IV drug abuse was detected in 08 (3.3\%). Homosexuality and heterosexuality were observed in $14(5.8 \%)$ and $12(4.9 \%)$ subjects respectively. History of dental procedure was seen in 31 (12.8\%). 228 (93.8\%) had history of needle pricking in different ways. History of different surgical procedures was observed in 33 (13.8\%). Calculated Mean and Standard Deviation for age was $39.2 \pm 10.3$ years. It was concluded that proper implementation of precautionary measures should be carried out for every human being to reduce burden of HCV illness in far near future.
\end{abstract}

\section{Keywords}

Viral Hepatitis C, Anti HCV Antibodies, Risk Factors 


\section{Introduction}

HCV (Hepatitis C virus) is widely spread in Islamic Republic of Pakistan and its load is anticipated to extend in upcoming decades due to extensive use of insecure medical practices. The occurrence of Hepatitis $\mathrm{C}$ virus infection in Pakistan had been evaluated in past and about 86 such researches were found in literature. Therefore, an improved modernized study was required to integrate the new information. A precise audit of information performed in vicinity of 2010 and 2015 demonstrated that HCV sero-prevalence amongst the common adult Pakistani populace was $6.8 \%$, while recent data on HCV established was around $06.0 \%$ of the populace. In most surveys, it was indicated that HCV infection was high in rural and peri urban areas (up to 25\%) [1]. Disease with hepatitis C virus $(\mathrm{HCV})$ is a noteworthy worldwide wellbeing concern. It is expected that about 170 million individuals are contaminated with HCV around the world, this ailment is turned out to be a heightening financial, social and wellbeing trouble [2] [3]. The weight of this sickness in a significant number of the developed and developing nations is consistently on the ascent [3]. Despite the fact that pervasiveness of $\mathrm{HCV}$ infection appears to have declined in the previous two decades in the vast majority of the developed nations of world like, USA, Europe (Western and Northern), Australia and Japan [4]-[9]. The occurrence of HCV differs by area. HCV occurrence less than $2 \%$ was noted in areas as America, Europe (Western) and Australia, while zones with the most astounding HCV infection are Africa and the Mediterranean (eastern) [10]. Hepatitis C Virus belongs to the family Flaviviridae with an around $9.6 \mathrm{~kb}$, single-stranded RNA genome. Due to poor constancy of HCV RNA dependent NS5B protein, the virus displays an abnormal state of arrangement heterogeneity [11]. In light of grouping homology six noteworthy HCV genotypes ( 1 - 6) and various distinctive subtypes e.g. $1 b, 3 a$ and so forth, have so far been recognized [12]. Hepatitis $C$ is the main source for end stage liver disease, including HCC (Hepatocellular carcinoma) and requirement for liver transplantation; recurrence of these were anticipated to build up 2 - 3 folds by 2030 [13]. Increased hazard of injection practices are the main source of HCV disease among drug abusers [14]. There were almost 13.2 million drug abusers around the world [15], and half of them appear to had been infected with HCV [16]. In Pakistan, there are different risk factors as compared to rest of globe. HCV infection transmission is usually related to infected blood (blood products), drug addicts (intravenous), and needle pricking mostly accidentally or peri-natal. Vertical and sexual routes are also reported as less frequent causes of HVC transmission [13].

This study was conducted at department of medicine Peoples Medical College Hospital Nawabshah, to identify the different risk factors in 243 anti HCV antibodies positive cases by ELISA. I believe that results of our study will be helpful in reduction of financial burden, quick identification and therefore reduce the morbidity and mortality. This study will be helpful for those who intend to do research work on chronic HCV infection, as well as for practicing physicians. 
Current research was aimed to identify different hazard factors among patients with HCV infection by analyzing their impact in our local community setup.

\section{Materials and Methods}

\subsection{Design and Participants}

This research (cross sectional) was carried out from April 2016 to March 2017, at the department of medicine PMC Hospital Peoples University of Medical and Health Sciences, all subjects from the local reporting community with sero-positive HCV antibodies were recruited for risk factor assessment. Sample size was 243 subjects, calculated by Rao-software calculator, with margin of error 5, CI 95 from total population about 1.6 Million. Different risk factors were identified in HCV positive cases from both genders aged between 18 to 60 years. All patients who visited first time and diagnosed as HCV positive willing for interview for identification of various risk factors were included in study. HCV patients with HbsAg and HIV were included in study. HbsAg and HIV without HCV were excluded. The monthly incomes of parents of all volunteers were divided into three categories. Income <Rs: 20,000/m (lower income class/Poor Peoples), Income $<$ Rs - 27,000 (middle income class) and Income $>$ Rs 28,000 (middle upper income class). Various risk factors with the help of available data like, Needle pricking barber shave, dental procedures, blood transfusion, homosexuality and heterosexuality Blood and its products, IV drug addiction dialysis, tattoo marks and HCV positive mothers were documented. Written informed consent was taken, risk stratification done based on history/interview and data was entered in the pre designed proforma.

\subsection{Questionnaire}

Trained doctors having perfect knowledge of subjects were involved to collect statistics by filling a proforma through interviews. Different demographic variables as history of drug abuse, and risk factor knowledge were included in proforma. Prior to enrollment, all the details were explained to the subjects and queries of subjects were explained them in detail for their satisfaction to participate in study.

\subsection{Ethical Considerations}

This study was carried out after permission of ethical committee; confidential information was collected from the subjects. After taking written consent the subjects were explained in detail regarding aims, risks, and positive outcome of playing a part in research. All of them were permitted to vacate the research at any moment.

\subsection{Statistical Analysis}

Variables (Continuous and Categorical) were evaluated for mean $\pm \mathrm{SD}$, frequency and percentage. The relationship among HCV condition and related risk 
issues were described as OR (odds ratio) and 95\% CI (confidence interval). Variables with $\mathrm{P} \leq 0.05$ were considered as significant. SPSS 20 version was adopted for collected information.

\section{Results}

In recent study there were total 243 patients of different age groups, all were Anti HCV antibodies positive; $165(67.9 \%)$ of these males and $78(32.1 \%)$ were from female gender. The mean age of subjects was 36.93 years with SD 11.347, minimum 18 years and maximum 60 years.

\subsection{Demographic Variables}

Patients were arranged in two age intervals, 146 (60.1\%) were between 18 and 40 years and 97 (39.9\%) were between 41 and 60 years. Married subjects were 230 (94.7\%) and 13 (5.3\%) were unmarried. In educational status 70\% (170) educated and 30\% (73) were uneducated. A majority of patients 186 (76.1\%) belonged to rural community and 58 (23.9\%) were from urban areas. no occupation in $39(16 \%)$ subjects, most of patients 109 (44.9\%) were manual workers, 78 (32.1\%) house wives and 17 (7\%) office workers. Large population of subjects were from lower class 217 (89.3\%), 21 (12.8\%) from middle and only $5(2.1 \%)$ subjects were from upper economical class Figure 1.

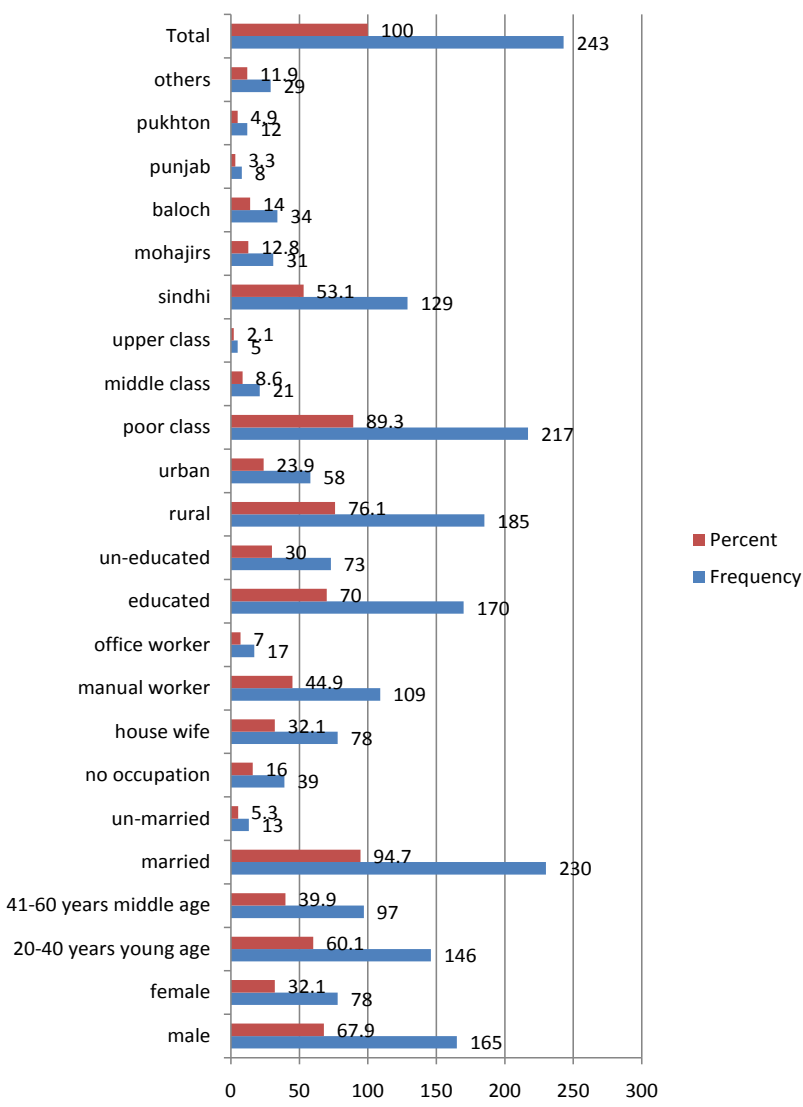

Figure 1. Demographic variables (risk factors) of viral hepatitis C. $n=243$. 


\subsection{Risk Factors for Hepatitis C}

Regarding the assessment of risk factors it was analyzed that most of the subjects have more than one risk factor. 19 (7.8\%) had history of transfusion (blood and blood products), out of them 15 males and 04 were females. IV drug abuse was detected in $8(3.3 \%)$, out of them 07 males and 01 female. Homosexuality and heterosexuality was observed in $14(5.8 \%)$ and 12 (4.9\%) subjects respectively. history of dental procedure was seen in $31(12.8 \%)$ with dominant male sex 24/31. Majority of subjects i.e. 228 (93.8\%) had history of needle pricking in different ways, out of these 154 male and 74 were females. History of different surgical procedures was observed in $33(13.8 \%)$ out of them females were 25 and 08 were male.

Out of 78 females 13 (16.66\%) female were un-married, while 25 (32.05\%) had history of safe delivery and $40(51.28 \%)$ had practiced home delivery. Only 01 $(0.4 \%)$ subject included in our study was on dialysis. Second most important risk factor among male was shaving from barbers present in 121 (49.8\%) out of 178 male subjects. Tattoo marking observed in $10(4.1 \%)$ and in $4.1 \%$ (10) of patients their mothers have positive history of HCV in past Table 1.

\subsection{Co-Morbidities}

Regarding the presence of co-morbidities it was observed that Hypertension, HBsAg, Diabetes Mellitus, Alcoholism and Smoking were associated with frequency of, 15 (6.2\%), 21 (8.6\%), 18 (7.4\%), 9 (3.7\%) and 35 (14.4\%) respectively Table 1.

\subsection{Correlation of Different Risk Factors with HCV}

The typical thing in our research was that in majority of patients there were more than one risk factor. IV drug addiction was less common in our locality, surgical and dental procedures, barber shave, safe delivery, needle prick and tattoo marks were special matter of concern to control. Pearson Correlation Sig. (2-tailed) of HCV was related to various risk factors which were statistically at significant levels. The correlation of blood and its products was not significant because of safe transfusion methods now a day due to proper screening of donors. Hepatitis $\mathrm{C}$ was a matter of concern in homosexual as well as heterosexuals. The correlations of various risk factors were shown in Table 2.

\subsection{Statistical Analysis of Risk Factors}

In present study male subjects were with dominant ratio. Needle pricking, barber shave, dental procedures, blood transfusion, homosexuality and heterosexuality were identified and risk stratified statistically for Pearson chi square, continuity correction, likelihood ratios, fisher extract and linear to linear associations in male and female subjects. Values like Pearson chi square, continuity correction, likelihood ratios, and fisher extract and linear to linear associations for heterosexual, homosexuals, surgical procedures, safe delivery, barber shave 
Table 1. Statistics of HCV risk factors and co-morbidities. $\mathrm{n}=243$.

\begin{tabular}{|c|c|c|c|c|c|c|}
\hline Risk Factors for HCV & Yes/No & Frequency & Percent & Chi-Square & df & Asymp. Sig. \\
\hline \multirow{2}{*}{$\begin{array}{l}\text { Blood Product } \\
\text { Transfusion }\end{array}$} & yes & 19 & 7.8 & \multirow[b]{2}{*}{172.942} & \multirow[b]{2}{*}{1} & \multirow[b]{2}{*}{0.000} \\
\hline & no & 224 & 92.2 & & & \\
\hline \multirow{3}{*}{ Iv Drug Addict } & yes & 8 & 3.3 & \multirow{3}{*}{212.035} & \multirow{3}{*}{1} & \multirow{3}{*}{0.000} \\
\hline & & & & & & \\
\hline & no & 235 & 96.7 & & & \\
\hline \multirow{3}{*}{ Heterosexual } & yes & 12 & 4.9 & \multirow{3}{*}{197.370} & \multirow{3}{*}{1} & \multirow{3}{*}{0.000} \\
\hline & & & & & & \\
\hline & no & 231 & 95.1 & & & \\
\hline \multirow{2}{*}{ Homosexuality } & yes & 14 & 5.8 & \multirow{2}{*}{190.226} & \multirow{2}{*}{1} & \multirow{2}{*}{0.000} \\
\hline & no & 229 & 94.2 & & & \\
\hline \multirow[b]{2}{*}{ Dental Procedures } & yes & 31 & 12.8 & \multirow[b]{2}{*}{134.819} & \multirow[b]{2}{*}{1} & \multirow[b]{2}{*}{0.000} \\
\hline & no & 212 & 872 & & & \\
\hline \multirow[b]{2}{*}{ Needle Pricking } & yes & 228 & 93.8 & \multirow[b]{2}{*}{186.704} & \multirow[b]{2}{*}{1} & \multirow[b]{2}{*}{0.000} \\
\hline & no & 15 & 6.2 & & & \\
\hline \multirow[b]{2}{*}{ Surgical Procedure } & yes & 33 & 13.6 & & & \\
\hline & no & 210 & 86.4 & 128.926 & 1 & 0.000 \\
\hline & yes & 25 & 10.3 & & & \\
\hline Safe Delivery & & & & 153.288 & 1 & 0.000 \\
\hline & no & 218 & 89.7 & & & \\
\hline & yes & 1 & 0.4 & & & \\
\hline Dialysis History & no & 242 & 99.6 & 239.016 & 1 & 0.000 \\
\hline & yes & 121 & 49.8 & & & \\
\hline Barber Shave & & & & .004 & 1 & 0.949 \\
\hline & no & 122 & 50.2 & & & \\
\hline Tatton Markino & yes & 10 & 4.1 & 204646 & 1 & 0000 \\
\hline 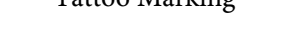 & no & 233 & 95.9 & 204.040 & 1 & 0.000 \\
\hline Patient Mother HCV & yes & 10 & 4.1 & 204616 & 1 & 0000 \\
\hline$+\mathrm{Ve}$ & no & 233 & 95.9 & 204.040 & 1 & 0.000 \\
\hline & & Co-mo & dity & & & \\
\hline & yes & 15 & 6.2 & & & \\
\hline Hypertension & No & 228 & 93.8 & $186.704 a$ & 1 & 0.000 \\
\hline & yes & 21 & 8.6 & & & \\
\hline HBsAg & No & 222 & 91.4 & $166.259 \mathrm{a}$ & 1 & 0.000 \\
\hline HIV & yes & 243 & 100.0 & Chi-squa & are $n$ & t applicable \\
\hline & No & 0 & 0.0 & & & \\
\hline & yes & 18 & 7.4 & & & \\
\hline Diabetes Mellitus & No & 225 & 92.6 & 176.333 & 1 & 0.000 \\
\hline & yes & 9 & 3.7 & 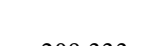 & 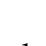 & 5000 \\
\hline AIcononism & No & 234 & 96.3 & 208.333 & 1 & 0.000 \\
\hline & yes & 35 & 14.4 & & & \\
\hline Smoking & No & 208 & 85.6 & 123.165 & 1 & 0.000 \\
\hline
\end{tabular}


Table 2. Correlation between different risk factors in subjects with HCV. $\mathrm{n}=243$.

\begin{tabular}{|c|c|c|c|c|c|c|c|c|c|c|c|c|c|}
\hline $\begin{array}{c}\text { Risk } \\
\text { Factor }\end{array}$ & $\begin{array}{c}\text { Statistical } \\
\text { test }\end{array}$ & $\begin{array}{c}\text { Blood/ } \\
\text { Products } \\
\text { Transfusion }\end{array}$ & $\begin{array}{c}\text { Iv } \\
\text { Drug } \\
\text { Addict }\end{array}$ & $\begin{array}{l}\text { Hetero- } \\
\text { sexual }\end{array}$ & $\begin{array}{l}\text { Homo- } \\
\text { sexuality }\end{array}$ & $\begin{array}{c}\text { Dental } \\
\text { Procedures }\end{array}$ & $\begin{array}{c}\text { Needle } \\
\text { Pricking }\end{array}$ & $\begin{array}{c}\text { Surgical } \\
\text { Procedure }\end{array}$ & $\begin{array}{c}\text { Safe } \\
\text { Delivery }\end{array}$ & $\begin{array}{l}\text { Dialysis } \\
\text { History }\end{array}$ & $\begin{array}{l}\text { Barber } \\
\text { Shave }\end{array}$ & $\begin{array}{c}\text { Tattoo } \\
\text { Marking }\end{array}$ & $\begin{array}{l}\text { Patient } \\
\text { Mother } \\
\mathrm{Hcv}+\mathrm{Ve}\end{array}$ \\
\hline $\begin{array}{l}\text { Blood/ } \\
\text { Product }\end{array}$ & $\begin{array}{c}\text { Pearson } \\
\text { Correlation }\end{array}$ & 1 & 0.032 & 0.004 & 0.06 & 0.026 & 0.075 & -0.071 & -0.048 & -0.019 & 0.047 & 0.017 & 0.017 \\
\hline Transfusion & Sig. (2-tailed) & & 0.618 & 0.946 & 0.355 & 0.681 & 0.246 & 0.272 & 0.455 & 0.772 & 0.464 & 0.794 & 0.794 \\
\hline \multirow{2}{*}{$\begin{array}{c}\text { Iv Drug } \\
\text { Addict }\end{array}$} & $\begin{array}{l}\text { Pearson } \\
\text { Correlation }\end{array}$ & 0.032 & 1 & 0.064 & 0.053 & 0.068 & 0.047 & -0.073 & -0.062 & -0.012 & $0.139^{\star}$ & -0.038 & 0.078 \\
\hline & Sig. (2-tailed) & 0.618 & & 0.317 & 0.408 & 0.293 & 0.463 & 0.256 & 0.332 & 0.854 & 0.03 & 0.553 & 0.226 \\
\hline \multirow{2}{*}{$\begin{array}{l}\text { Hetero- } \\
\text { sexual }\end{array}$} & $\begin{array}{l}\text { Pearson } \\
\text { Correlation }\end{array}$ & 0.004 & 0.064 & 1 & -0.056 & $0.198^{* *}$ & 0.058 & -0.09 & -0.077 & -0.015 & $0.153^{\star}$ & 0.048 & -0.047 \\
\hline & Sig. (2-tailed) & 0.946 & 0.317 & & 0.382 & 0.002 & 0.364 & 0.16 & 0.231 & 0.82 & 0.017 & 0.453 & 0.464 \\
\hline \multirow{2}{*}{$\begin{array}{l}\text { Homo- } \\
\text { sexuality }\end{array}$} & $\begin{array}{l}\text { Pearson } \\
\text { Correlation }\end{array}$ & 0.06 & 0.053 & -0.056 & 1 & -0.042 & 0.063 & -0.046 & -0.084 & -0.016 & 0.107 & -0.051 & -0.051 \\
\hline & Sig. (2-tailed) & 0.355 & 0.408 & 0.382 & & 0.519 & 0.325 & 0.471 & 0.193 & 0.805 & 0.096 & 0.427 & 0.427 \\
\hline \multirow{2}{*}{$\begin{array}{c}\text { Dental } \\
\text { Procedure }\end{array}$} & $\begin{array}{l}\text { Pearson } \\
\text { Correlation }\end{array}$ & 0.026 & 0.068 & $0.198^{\star *}$ & -0.042 & 1 & 0.098 & -0.044 & -0.008 & -0.025 & 0.014 & $0.169^{\star *}$ & -0.079 \\
\hline & Sig. (2-tailed) & 0.681 & 0.293 & 0.002 & 0.519 & & 0.127 & 0.499 & 0.905 & 0.703 & 0.829 & 0.008 & 0.219 \\
\hline \multirow{2}{*}{$\begin{array}{c}\text { Needle } \\
\text { Pricking }\end{array}$} & $\begin{array}{l}\text { Pearson } \\
\text { Correlation }\end{array}$ & 0.075 & 0.047 & 0.058 & 0.063 & 0.098 & 1 & 0.102 & 0.087 & 0.016 & 0.016 & 0.053 & 0.053 \\
\hline & Sig. (2-tailed) & 0.246 & 0.463 & 0.364 & 0.325 & 0.127 & & 0.114 & 0.177 & 0.798 & 0.803 & 0.41 & 0.41 \\
\hline \multirow{2}{*}{$\begin{array}{l}\text { Surgical } \\
\text { Procedure }\end{array}$} & $\begin{array}{l}\text { Pearson } \\
\text { Correlation }\end{array}$ & -0.071 & -0.073 & -0.09 & -0.046 & -0.044 & 0.102 & 1 & $0.815^{\star *}$ & $0.162^{\star}$ & $-0.251^{\star *}$ & $0.220^{\star *}$ & -0.082 \\
\hline & Sig. (2-tailed) & 0.272 & 0.256 & 0.16 & 0.471 & 0.499 & 0.114 & & 0 & 0.011 & 0 & 0.001 & 0.202 \\
\hline \multirow{2}{*}{$\begin{array}{c}\text { Safe } \\
\text { Delivery }\end{array}$} & $\begin{array}{l}\text { Pearson } \\
\text { Correlation }\end{array}$ & -0.048 & -0.062 & -0.077 & -0.084 & -0.008 & 0.087 & $0.815^{\star *}$ & 1 & -0.022 & $-0.310^{* *}$ & $0.203^{* *}$ & -0.07 \\
\hline & Sig. (2-tailed) & 0.455 & 0.332 & 0.231 & 0.193 & 0.905 & 0.177 & 0 & & 0.736 & 0 & 0.001 & 0.276 \\
\hline \multirow{2}{*}{$\begin{array}{l}\text { Dialysis } \\
\text { History }\end{array}$} & $\begin{array}{l}\text { Pearson } \\
\text { Correlation }\end{array}$ & -0.019 & -0.012 & -0.015 & -0.016 & -0.025 & 0.016 & $0.162^{\star}$ & -0.022 & 1 & -0.064 & -0.013 & -0.013 \\
\hline & Sig. (2-tailed) & 0.772 & 0.854 & 0.82 & 0.805 & 0.703 & 0.798 & 0.011 & 0.736 & & 0.32 & 0.836 & 0.836 \\
\hline \multirow{2}{*}{$\begin{array}{l}\text { Barber } \\
\text { Shave }\end{array}$} & $\begin{array}{l}\text { Pearson } \\
\text { Correlation }\end{array}$ & 0.047 & $0.139^{*}$ & $0.153^{*}$ & 0.107 & 0.014 & 0.016 & $-0.251^{\star *}$ & $-0.310^{\star *}$ & -0.064 & 1 & -0.082 & -0.041 \\
\hline & Sig. (2-tailed) & 0.464 & 0.03 & 0.017 & 0.096 & 0.829 & 0.803 & 0 & 0 & 0.32 & & 0.203 & 0.529 \\
\hline \multirow{2}{*}{$\begin{array}{l}\text { Tattoo } \\
\text { Marking }\end{array}$} & $\begin{array}{l}\text { Pearson } \\
\text { Correlation }\end{array}$ & 0.017 & -0.038 & 0.048 & -0.051 & $0.169^{* *}$ & 0.053 & $0.220^{\star \star}$ & $0.203^{\star *}$ & -0.013 & -0.082 & 1 & -0.043 \\
\hline & Sig. (2-tailed) & 0.794 & 0.553 & 0.453 & 0.427 & 0.008 & 0.41 & 0.001 & 0.001 & 0.836 & 0.203 & & 0.505 \\
\hline $\begin{array}{l}\text { Patient } \\
\text { Mother }\end{array}$ & $\begin{array}{l}\text { Pearson } \\
\text { Correlation }\end{array}$ & 0.017 & 0.078 & -0.047 & -0.051 & -0.079 & 0.053 & -0.082 & -0.07 & -0.013 & -0.041 & -0.043 & 1 \\
\hline $\mathrm{HCV}+\mathrm{Ve}$ & Sig. (2-tailed) & 0.794 & 0.226 & 0.464 & 0.427 & 0.219 & 0.41 & 0.202 & 0.276 & 0.836 & 0.529 & 0.505 & \\
\hline
\end{tabular}

and tattoo marks were statistical significant. Blood and its products, IV drug addiction, needle pricking, dialysis and HCV positive mothers were statistically insignificant as shown in Table 3.

\section{Discussion}

Pakistan is a country where majority of population is from low socioeconomic class and facing a lot of health related problems. Educational profile is still low in rural areas while improving in urban areas. Nowadays government of Pakistan is 
Table 3. Statistical analysis of various risk factors in relation to gender in hepatitis C positive cases. Cross tabulation. $\mathrm{n}=243$.

\begin{tabular}{|c|c|c|c|c|c|c|c|c|c|c|}
\hline \multirow[b]{2}{*}{ Variable } & \multicolumn{2}{|c|}{ Male } & \multicolumn{2}{|c|}{ Female } & \multirow[b]{2}{*}{ Total } & \multirow{2}{*}{$\begin{array}{c}\text { Pearson } \\
\text { Chi-square } \\
\text { Asymp Sig. } \\
\text { (2-sided) }\end{array}$} & \multirow{2}{*}{$\begin{array}{c}\text { Continuity } \\
\text { Correction } \\
\text { Asymp Sig. } \\
\text { (2-sided) }\end{array}$} & \multirow{2}{*}{$\begin{array}{l}\text { Likelyhood } \\
\text { Ratio } \\
\text { Asymp Sig. } \\
\text { (2-sided) }\end{array}$} & \multicolumn{2}{|c|}{ Fisher extract L/L Associations } \\
\hline & $\begin{array}{c}\text { Yes } \\
\mathrm{n}\end{array}$ & $\begin{array}{c}\text { No } \\
\mathrm{n}\end{array}$ & $\begin{array}{c}\text { Yes } \\
\mathrm{n}\end{array}$ & $\begin{array}{c}\text { No } \\
\mathrm{n}\end{array}$ & & & & & $\begin{array}{l}\text { Exact Sig. } \\
\text { (2-sided) }\end{array}$ & $\begin{array}{l}\text { Asymp. Sig. } \\
\text { (2-sided) }\end{array}$ \\
\hline $\begin{array}{l}\text { Blood \& Blood } \\
\text { products }\end{array}$ & 15 & 150 & 4 & 74 & 243 & 0.283 & 0.413 & 0.266 & 0.443 & 0.284 \\
\hline IV drug Addict & 7 & 158 & 1 & 77 & 243 & 0.277 & 0.411 & 0.191 & 0.422 & 0.228 \\
\hline Heterosexual & 12 & 153 & 0 & 78 & 243 & 0.015 & 0.034 & 0.002 & 0.011 & 0.015 \\
\hline Homosexual & 14 & 151 & 0 & 78 & & 0.008 & 0.019 & 0.001 & 0.006 & 0.008 \\
\hline Dental Procedures & 24 & 141 & 7 & 71 & 243 & 0.224 & 0.313 & 212 & 0.303 & 0.225 \\
\hline Needle Pricking & 154 & 11 & 74 & 4 & 243 & 0.642 & 0.857 & 0.637 & 0.780 & 0.642 \\
\hline Surgical Procedure & 8 & 157 & 25 & 53 & 243 & 0.000 & 0.000 & 0.000 & 0.000 & 0.000 \\
\hline Safe Delivery & 0 & 0 & 24 & 54 & 78 & 0.000 & 0.000 & 0.000 & 0.000 & 0.000 \\
\hline Dialysis & 1 & 164 & 0 & 78 & 243 & 0.491 & 10.000 & 0.378 & 10.000 & 0.492 \\
\hline Barber Shave & 121 & 44 & 0 & 78 & 243 & 0.000 & 0.000 & 0.000 & 0.000 & 0.000 \\
\hline Tattoo Marks & 4 & 161 & 6 & 72 & 243 & 0.054 & 0.113 & 0.064 & 0.080 & 0.054 \\
\hline $\begin{array}{c}\text { Patient Mother } \\
\mathrm{HCV}+\mathrm{Ve}\end{array}$ & 5 & 160 & 5 & 73 & 243 & 0.216 & 0.372 & 0.231 & 0.298 & 0.217 \\
\hline
\end{tabular}

directly involved to control and treat hepatitis $\mathrm{C}$ at national level. Present research deeply concerned with wide spreading of viral hepatitis $\mathrm{C}$ in population and looked upon the risk factors in subjects of chronic hepatitis $\mathrm{C}$, in Pakistan. Viral Hepatitis $\mathrm{C}$ is worldwide issue in humans and Pakistan is also affected on large scale. It is targeted by WHO (world health organization) to eliminate the HCV infection form the Globe by 2030 [17]. Early identification and elimination of risk factors is essential to control the disease prevalence and incidence worldwide.

In current study, a considerable relationship among HCV infection and risk factors were analyzed which were similar to the previous studies. Studies conducted in Iran analyzed strong association of HCV seropositivity and length and number of injection, tattooing, sharing equipment and history of imprison in subjects [18] [19] [20]. In current research risk factors were identified, repeated/ multiple injections was observed in 228 (93.8\%) patients, tattoo marks in 10 (4.1\%). No prisoner was registered in current study.

In Pakistan 15\% were habitual IV drug abusers from 05 million addicts [21]. The addicts had used other injectable drugs so there was alteration from inhalation to injections [22]. The occurrence of HCV in IV drug abusers as reported in different studies was as high as $57 \% \pm 17.7 \%$ [23] [24] [25] [26]. In our setup addiction rate in study was low $3.3 \%$ in comparison to other studies. Findings of present study were different from the others. HCV was reported as $48.67 \% \pm$ $1.75 \%$ in subjects with blood disorders [27]-[33]. In present study $7.8 \%$ subjects had history of transfusion.

Needle pricking during recapping the syringes accounts for $2 \%-10 \%$ trans- 
mission of HCV especially in health care workers [34] [35] [36]. No health care worker was registered in current research.

Illiteracy, lack of health education, decreased sex knowledge is the most important difficulties in our population. In $20 \%$ of naive USA, infection with HCV reported to be related with sexual involvement [37]. The demography of present study shown that 73 subjects were uneducated and on contrary the educated was 170 but majority of them were below matriculation. Low education may be the contributing factor to transmission of HCV.

Studies had shown decreased incidence of $\mathrm{HCV}$ infection in sex workers (commercial) [38] [39]. Constant uses of condoms were observed in sex workers (women $17 \%$ and men $3 \%$ ) and $4 \%$ in Hijras (transgender). In street children activities like homosexuality were very common and with passage of time these activities assumed into commercial sex and condom use in (homosexuals) were very lacking [40]. Inter spousal incidence of HCV was reported as $17.24 \% \pm$ $7.98 \%$ in different studies [41] [42] [43] [44]. No permission for commercial sex in Pakistan. But homosexuality and heterosexuality both are common hidden practices in our setup. In present research, we had registered very low number of sex offenders because of psychosocial and religious concern.

In Hyderabad, Sukkur and Mirpur Khas sharing of injection equipment was observed in $8.5 \%, 33.6 \%$ and $68.0 \%$ respectively [25] [45]. In current research there were 228 (93.8\%) subjects with history of needle pricking by non-medical and medical professionals, accidently or nose and ear piercing. Needle pricking ratio was very high and strong risk predictor for HCV infection in local setup.

In Pakistan round about 1.2 - 1.5 million transfusions are given each year as reported by W.H.O [46] Study conducted by Luby et al. analyzed that $23 \%$ blood banks routinely screen for HCV, and 25\% of Blood Banks didn't fulfill WHO criterion for storing the collected blood. About $66 \%$ of Pakistani populace belongs to the rural community where blood transfusion facilities are insufficient. Professional donors should be discouraged to promote the hazardous free blood supply [47]. In our setup many of rural health centers lacks the proper equipments and screening facilities even in Talka hospitals and District hospitals the screening methods are very poor and matter of concern.

Barbers in Pakistan and other developing nations are mostly illiterate and had no knowledge of health related infectious mediators which they spread through reuse of unsterilized razors and scissors [48]. Approximately 13\% of barbers were aware that hepatitis could be transmitted by contaminated razors/scissors etc [49]. Studies had analyzed that most of the barbers were not knowing about $\mathrm{HCV}$ infection and performing shavings in contaminated conditions [50]. Viral hepatitis $\mathrm{C}$ was present in $70.0 \%$ of facial and $48.0 \%$ of axillary shavings by barbers [51]. In current study, 121 (73.33\%) male subjects had history of barber shavings most of them were with low educational level and were unaware of HCV transmission from the barber's shavings (face and armpit).

Circumcision is a religious practice, earlier this was done by the commercial barbers by unsterilized equipments [50]. Major and minor surgical procedures 
were also analyzed in current study except circumcision. History of surgery in 08 males and 25 female subjects, dental procedure in 24 males and 07 females and history of safe delivery was present in 25 females.

It is recommended that there should be a national screening plan for hepatitis C. All subjects who are at risk in population must be investigated earlier. Steps should be taken to control risk factors. Screening program at national level should be started in early childhood to all ages.

Early diagnosis and prompt treatment at standard levels (recommended by WHO/FDA and other international agencies) should be applied at large scale. Medical surgical and dental instruments should be checked at international standards to avoid contamination. Sterilization levels should be improved at protocol levels. Health education may play vital role in control of different preventable risk factors. It is responsibility of government and public sector that they should be aware and have an eagle eye on this current issue of morbidity and mortality.

\section{Conclusion}

$\mathrm{HCV}$ there is a big financial burden on public and government, most of our population belongs to lower economic class and cannot afford the treatment and management of hepatitis $\mathrm{C}$ alone or with its complications. Needle pricking, barber shaving, blood and its products and dental procedures are common risk factors in our research. While IV addictions, heterosexuals, homosexuals, unsafe delivery methods, dialysis, tattoo markings and vertical transmission from mothers to off springs were identified main contributing risk factors of present study. It is concluded that proper implementation of precautionary measurements should be carried out for every one human being to reduce contact of $\mathrm{HCV}$ illness in far near future.

\section{Recommendations}

A large study for the screening of HCV should be carried out at national level to check the exact possible prevalence of HCV infection in Pakistan. All age groups and genders should be involved. At national level total prevalent risk factors should be identified and all should be assessed for modifications. Valid steps should be taken to control the risk factors. All governmental and nongovernmental organizations at national and international levels should be involved to control various risk factors. Health education at national levels should be implanted

Monitoring agencies should work at ground root levels to control the situation

\section{Limitations}

This was a small size study in our local setup.

Only those subjects were included who came after diagnosis for treatment. 
The status of community exposed / unexposed was unknown.

\section{Funding}

This study was not funded by any organization.

\section{Conflict of Interest}

Author declares that he has no conflict of interest.

\section{References}

[1] Umer, M. and Iqbal, M. (2016) Hepatitis C Virus Prevalence and Genotype Distribution in Pakistan: Comprehensive Review of Recent Data. World Journal of Gastroenterology, 22, 1684-1700. https://doi.org/10.3748/wjg.v22.i4.1684

[2] Lavanchy, D. (2011) Evolving Epidemiology of Hepatitis C Virus. Clinical Microbiology and Infection, 17, 107-115. https://doi.org/10.1111/j.1469-0691.2010.03432.x

[3] Hajarizadeh, B., Grebely, J. and Dore, G.J. (2013) Epidemiology and Natural History of HCV Infection. Nature Reviews Gastroenterology \& Hepatology, 10, 553-562. https://doi.org/10.1038/nrgastro.2013.107

[4] Armstrong, G.L., Wasley, A., Simard, E.P., McQuillan, G.M., Kuhnert, W.L. and Alter, M.J. (2006) The Prevalence of Hepatitis C virus Infection in the United States, 1999 through 2002. Annals of Internal Medicine, 144, 705-714. https://doi.org/10.7326/0003-4819-144-10-200605160-00004

[5] Williams, I.T., Bell, B.P., Kuhnert, W. and Alter, M.J. (2011) Incidence and Transmission Patterns of Acute Hepatitis C in the United States, 1982-2006. Archives of Internal Medicine, 171:242-248. https://doi.org/10.1001/archinternmed.2010.511

[6] Duberg, A., Janzon, R., Bäck, E., Ekdahl, K. and Blaxhult, A. (2008) The Epidemiology of Hepatitis C Virus Infection in Sweden. Eurosurveillance, 13, 18882.

https://doi.org/10.2807/ese.13.21.18882-en

[7] Delarocque-Astagneau, E., Meffre, C., Dubois, F., Pioche, C., Le Strat, Y., Roudot-Thoraval, F., Hillon, P., Silvain, C., Dhumeaux, D. and Desenclos, J.C. (2010) The Impact of the Prevention Programme of Hepatitis C over more than a Decade: the French Experience. Journal of Viral Hepatitis, 17, 435-443. https://doi.org/10.1111/j.1365-2893.2009.01196.x

[8] Chung, H., Ueda, T. and Kudo, M. (2010) Changing Trends in Hepatitis C Infection over the past 50 Years in Japan. Intervirology, 53, 39-43. https://doi.org/10.1159/000252782

[9] Razali, K., Thein, H.H., Bell, J., Cooper-Stanbury, M., Dolan, K., Dore, G., George, J., Kaldor, J., Karvelas, M., Li, J., et al. (2007) Modelling the Hepatitis C Virus Epidemic in Australia. Drug and Alcohol Dependence, 91, 228-235. https://doi.org/10.1016/j.drugalcdep.2007.05.026

[10] Lavanchy, D. (2009) The Global Burden of Hepatitis C. Liver International, 29, 74-81. https://doi.org/10.1111/j.1478-3231.2008.01934.x

[11] Moradpour, D., Penin, F. and Rice, C.M. (2007) Replication of Hepatitis C Virus. Nature Reviews Microbiology, 5, 453-463. https://doi.org/10.1038/nrmicro1645

[12] WHO (2003) Epidemic and Pandemic Alert and Response, Hepatitis C Virus. http://www.who.int/csr/disease/hepatitis/whocdscsrlyo2003/en/index2.html

[13] Dufour, R. (2004) Lot to Lot Variation in Anti-Hepatitis C Signal-to-Cutoff Ratio. Clinical Chemistry, 50, 958-960. https://doi.org/10.1373/clinchem.2003.031039 
[14] Rezaie, F., Noroozi, A., Armoon, B., Farhoudian, A., Massah, O., Sharifi, H., et al. (2017) Social Determinants and Hepatitis c among People Who Inject Drugs in Kermanshah, Iran: Socioeconomic Status, Homelessness, and Sufficient Syringe Coverage. Journal of Substance Use, 22, 1-5. https://doi.org/10.1373/clinchem.2003.031039

[15] Aceijas, C., Stimson, G.V., Hickman, M. and Rhodes, T. (2004) United Nations Reference Group on HP, Care among ID, et al. Global Overview of Injecting Drug Use and HIV Infection among Injecting Drug Users. AIDS, 18, 2295-2303. https://doi.org/10.1097/00002030-200411190-00010

[16] Aceijas, C. and Rhodes, T. (2007) Global Estimates of Prevalence of HCV Infection among Injecting Drug Users. International Journal of Drug Policy, 18, 352-358. https://doi.org/10.1016/j.drugpo.2007.04.004

[17] World Health Statistics (2016) Monitoring Health for the SDGs Sustainable Development Goals.

[18] Mir-Nasseri, M.M., Mohammadkhani, A., Tavakkoli, H., Ansari, E. and Poustchi, H. (2011) Incarceration Is a Major Risk Factor for Blood-Borne Infection among Intravenous Drug Users: Incarceration and Blood Borne Infection among Intravenous Drug Users. Hepatitis Monthly, 11, 19-22.

[19] Nokhodian, Z., Meshkati, M., Adibi, P., Ataei, B., Kassaian, N., Yaran, M., et al. (2012) Hepatitis c among Intravenous Drug Users in Isfahan, Iran: A Study of Seroprevalence and Risk Factors. International Journal of Preventive Medicine, 3, 131-138.

[20] Sharhani, A., Mehrabi, Y., Noroozi, A., Nasirian, M., et al. (2017) Hepatitis C Virus Seroprevalence and Associated Risk Factors among Male Drug Injectors in Kermanshah, Iran. Hepatitis Monthly, 17, e58739.

https://doi.org/10.5812/hepatmon.58739

[21] United Nations Office for Drug Control and Crime Prevention (2002) Global Illicit Drug Trend. United Nations, New York.

[22] Shah, S.A. and Altaf, A. (2006) Prevention and Control of HIV/AIDS among Injection Drug Users in Pakistan: A Great Challenge. The Journal of the Pakistan Medical Association, 56, S75-S76.

[23] Kuo, I., ul-Hasan, S., Galai, N., Thomas, D.L., Zafar, T., Ahmed, M.A. and Strathdee, S.A. (2006) High HCV Seroprevalence and HIV Drug Use Risk Behaviors among Injection Drug Users in Pakistan. Harm Reduction Journal, 3, 26. https://doi.org/10.1186/1477-7517-3-26

[24] Achakzai, M., Kassi, M. and Kasi, P.M. (2007) Seroprevalences and Co-Infections of HIV, Hepatitis C Virus and Hepatitis B Virus in Injecting Drug Users in Quetta, Pakistan. Tropical Doctor, 37, 43-45. https://doi.org/10.1258/004947507779951989

[25] Altaf, A., Saleem, N., Abbas, S. and Muzaffar, R. (2009) High Prevalence of HIV Infection among Injection Drug Users (IDUs) in Hyderabad and Sukkur, Pakistan. The Journal of the Pakistan Medical Association, 59, 136-140.

[26] Platt, L., Vickerman, P., Collumbien, M., Hasan, S., Lalji, N., Mayhew, S., Muzaffar, R., Andreasen, A. and Hawkes, S. (2009) Prevalence of HIV, HCV and Sexually Transmitted Infections among Injecting Drug Users in Rawalpindi and Abbottabad, Pakistan: Evidence for an Emerging Injection-Related HIV Epidemic. Sexually Transmitted Infections, 85, ii17-ii22. https://doi.org/10.1136/sti.2008.034090

[27] Arif, F., Fayyaz, J. and Hamid, A. (2008) Awareness among Parents of Children with Thalassemia Major. The Journal of the Pakistan Medical Association, 58, 621-624. 
[28] Malik, N. and Hussain, Z. (2006) Markers of Viral Hepatitis in Hemophiliacs. Biomedica, 22, 48-50.

[29] Bhatti, F.A., Amin, M. and Saleem, M. (1995) Prevalence of Anti Body to Hepatitis C Virus in Pakistani Thalassaemics by Particle Agglutination Test Utilizing C 200 and C22-3 Viral Antigen Coated Proteins. The Journal of the Pakistan Medical As sociation, 45, 269-271.

[30] Muhammad, J., Hussain, M. and Khan, M.A. (2003) Frequency of Hepatitis B and Hepatitis C Infection in Thalassemic Children. Pakistan Pediatric Journal, 27, 161-164.

[31] Shah, S.M.A., Khan, M.T., Zahour, U. and Ashfaq, N.Y. (2005) Prevalence of Hepatitis B and Hepatitis C Virus Infection in Multitransfused Thalassaemia Major Patients in North West Frontier Province. Pakistan Journal of Medical Sciences, 21, 281-284.

[32] Hussain, H., Iqbal, R., Khan, M.H., Iftikhar, B., Aziz, S. and Burki, F.K. (2008) Prevalence of Hepatitis C in Beta Thalassaemia Major. Gomal Journal of Medical Sciences, 6, 87-90.

[33] Hussain, M., Khan, M.A., Muhammad, J. and Jan, A. (2003) Frequency of Hepatitis B and C in Hemophiliac Children. Pakistan Pediatric Journal, 27, 157-160.

[34] Hamid, S.S., Farooqui, B., Rizvi, Q., Sultana, T. and Siddiqui, A.A. (1999) Risk of Transmission and Features of Hepatitis $\mathrm{C}$ after Needle Stick Injuries. Infection Control \& Hospital Epidemiology, 20, 63-64. https://doi.org/10.1086/501547

[35] Mujeeb, S.A., Khatri, Y. and Khanani, R. (1998) Frequency of Parenteral Exposure and Seroprevalence of HBV, HCV, and HIV among Operation Room Personnel. Journal of Hospital Infection, 38, 133-137. https://doi.org/10.1016/S0195-6701(98)90066-4

[36] Aziz, S., Memon, A., Tily, H.I., Rasheed, K., Jehangir, K. and Quraishy, M.S. (2002) Prevalence of HIV, Hepatitis B and C amongst Health Workers of Civil Hospital Karachi. The Journal of the Pakistan Medical Association, 52, 92-94.

[37] Alter, M.J. (1999) Hepatitis C Virus Infection in the United States. Journal of Hepatology, 31, 88-91. https://doi.org/10.1016/S0168-8278(99)80381-X

[38] Buffington, J., Murray, P.J., Schlanger, K., Shih, L., Badsgard, T., Hennessy, R.R., Wood, R., Weisfuse, I.B. and Gunn, R.A. (2007) Low Prevalence of Hepatitis C Virus Antibody in Men Who Have Sex with Men Who Do Not Inject Drugs. Public Health Reports, 122, 63-67. https://doi.org/10.1177/00333549071220S212

[39] Laurent, C., Henzel, D., Mulanga-Kabeya, C., Maertens, G., Larouzé, B. and Delaporte, E. (2001) Seroepidemiological Survey of Hepatitis C Virus among Commercial Sex Workers and Pregnant Women in Kinshasa, Democratic Republic of Congo. International Journal of Epidemiology, 30, 872-877. https://doi.org/10.1093/ije/30.4.872

[40] Saleem, N.H., Adrien, A. and Razaque, A. (2008) Risky Sexual Behavior, Knowledge of Sexually Transmitted Infections and Treatment Utilization among a Vulnerable Population in Rawalpindi, Pakistan. The Southeast Asian Journal of Tropical Medicine and Public Health, 39, 642-648.

[41] Irfan, A. and Arfeen, S. (2004) Hepatitis C Virus Infection in Spouses. Pakistan Journal of Medical Research, 43, 113-116.

[42] Kumar, N., Sattar, R.A. and Ara, J. (2004) Frequency of Hepatitis C Virus in the Spouses of HCV Positive Patients and Risk Factors for Two Groups. Journal of Surgery Pakistan, 9, 36-39. 
[43] Khokher, N., Gill, M.L. and Alam, A.Y. (2005) Interspousal Transmission of Hepatitis C Virus. Journal of the College of Physicians and Surgeons, 15, 587-589.

[44] Qureshi, H., Arif, A., Ahmed, W. and Alam, S.E. (2007) HCV Exposure in Spouses of the Index Cases. The Journal of the Pakistan Medical Association, 57, 175-177.

[45] Janjua, N.Z., Akhtar, S. and Hutin, Y.J. (2005) Injection Use in Two Districts of Pakistan: Implications for Disease Prevention. International Journal for Quality in Health Care, 17, 401-408. https://doi.org/10.1093/intqhc/mzi048

[46] Asif, N., Kokhar, N. and Ilahi, F. (2004) Seroprevalence of HBV, HCV and HIV Infection among Voluntary Non Remunerated and Replacement Donors in Northern Pakistan. Pakistan Journal of Medical Sciences, 20, 24-28.

[47] Luby, S., Khanani, R., Zia, M., et al. (2000) Evaluation of Blood Bank Practices in Karachi, Pakistan, and the Government's Response. Health Policy Plan, 15, 217-222. https://doi.org/10.1093/heapol/15.2.217

[48] Khaliq, A.A. and Smego, R.A. (2005) Barber Shaving and Blood-Borne Disease Transmission in Developing Countries. South African Medical Journal, 95, 94-96.

[49] Janjua, N.Z. and Nizamy, M.A. (2004) Knowledge and Practices of Barbers about Hepatitis B and C Transmission in Rawalpindi and Islamabad. The Journal of the Pakistan Medical Association, 54, 116-119.

[50] Wazir, M.S., Mehmood, S., Ahmed, A. and Jadoon, H.R. (2008) Awareness among Barbers about Health Hazards Associated with Their Profession. Journal of Ayub Medical College Abbottabad, 20, 35-38.

[51] Bari, A., Akhtar, S., Rahbar, M.H. and Luby, S.P. (2001) Risk Factors for Hepatitis C Virus Infection in Male Adults in Rawalpindi-Islamabad, Pakistan. Tropical Medicine \& International Health, 6, 732-738. https://doi.org/10.1046/j.1365-3156.2001.00779.x 